In New Jersey, cotton fabric and tar were applied on 600 linear $\mathrm{ft}$. of a gravel road in South Brunswick township. After a year of service an inspection was made. Due to snow and light rain for two days the road and adjoining ground was saturated. On the part of the road where the fabric had not been used, the surface was broken in twelve places. Brokén areas were $0 \cdot 5-1 \cdot 5 \mathrm{sq}$. $\mathrm{ft}$. in area and were quite soft. In other places the surface was resilient and water would ooze to the surface under pressure with a blunt instrument. On the other hand, there were no broken places in the section which had been treated with cotton fabric, and the surface was tougher and less easily punctured with a screwdriver. Recent reports sent in from a number of highway departments indicate that short test sections of bituminoussurfaced roads, having cotton as part of their construction, have decreased maintenance costs and require less patching. The South Carolina Highway Department has used cotton fabric on bridge surfaces also with a marked degree of improvement in maintaining a satisfactory bituminous surface.

\section{Progress in Stereo Plate Casting}

A PAPER on stereo plate casting published in the Electrical Review of March 8 gives a survey of the progress made in the application of electric heating to autoplate machines for the production of stereo plates for rotary printing presses. For several years past much has been done in the United States, and pioneer work in England took place so long ago as 1930 at the Daily Mail offices in Manchester, where four electrically heated autoplate machines loaded at 120 kilowatts each represented, it is claimed, the first electric printing works foundry in Europe. The next major move was not until about a year ago, when Allied Newspapers Ltd. decided to electrify completely the autoplate installation at their Manchester offices.

The electric autoplates are fitted with baths each having a capacity of about $7 \frac{1}{2}$ tons of stereo metal, which, when casting is in progress, is kept molten at about $650^{\circ} \mathrm{F}$. and at about $450^{\circ} \mathrm{F}$. during stand-by periods. It takes about two minutes to raise the temperature from $450^{\circ}$ to $650^{\circ} \mathrm{F}$. The special immersion heaters are of grid construction, and in the largest machines have an installed heating load of $264 \mathrm{kw}$. This is probably the first time that metalsheathed tubular heaters have been directly immersed in cast metal, and the result has been most efficient operation. Since the completion of the Allied Newspapers installation, electric heating has also been introduced at the foundries in Manchester of Odhams Press, Ltd., and the Manchester Guardian. In the later units there is automatic temperature control.

\section{Carnegie Trust for Scottish Universities}

THE latest report of the Carnegie Trust for the Universities of Scotland shows the varied and substantial aid given. The grants are arranged in quinquennial distributions, the seventh of which covers the years 1935-1940. An aggregate of $£ 257,300$ was allocated to the universities and extra-mural institutions. The Trust is generally associated with libraries and students' fees, but it also does a good deal for specialists engaged in scientific research, and it is satisfactory to read the good reports of their work, which is as wide as in former years, and maintains an excellent standard. Several of the fellows and scholars have secured places which render them independent of the Trust. The subjects studied range from the Atlantic grey seal in the Western Islands to protein metabolism and a new synthesis of compounds of therapeutic value. The Trust subscribes to the production of good books not likely to have a popular sale and to such enterprises as a further study of the Roman occupation of southern Scotland, aided by spotting from the air.

We notice in detail that in the Glasgow, Edinburgh, and Aberdeen centres agricultural colleges have received $£ 200$ a year each. St. Andrews has had $£ 33,150$ for alterations and extensions in the five years, and Glasgow, towards the cost of the new Chemistry Institute, $£ 59,000$. The Edinburgh accounts include $£ 13,000$ for a lecturer in English, also large sums for the endowment of prehistoric archæology and ethnology, while the Men's and Women's Unions are each put down for $£ 3,000$. Equipment for medical departments of the University comes to $£ 7,250$. Arrangements have been made to meet the difficulties caused by the War.

\section{Chemical Research in Australia}

THe Commonwealth Government has approved a further addition to the activities of the Council for Scientific and Industrial Research. A division of industrial chemistry is to be established with headquarters adjoining the recently erected Aeronautical Research Laboratory at Fisherman's Bend, Port Melbourne. $£ 50,000$ has been provided for the initial building and its equipment, and abundant space is available for later extensions. After prolonged discussions with leading industrialists, it has been decided to concentrate upon study of certain aspects of each of the following major lines: (1) nonmetallic minerals and their utilization; (2) metals and alloys, particularly from the point of view of corrosion; (3) leather, hides and fellmongery; (4) dairy products; with (5) a miscellaneous group where work will begin on paints and varnishes. Dr. I. W. Wark has been appointed to control the work of the division.

\section{Minerals of Canada}

A usEFux publication which has made its annual appearance is "The Canadian Mineral Industry in 1938" (Dept. of Mines and Resources, Mines and Geology Branch, No. 804. 25 cents). It gives the output of all important mines in Canada and the destination and use of the product. It is noteworthy that Canada, in its pitchblende deposit near the Great Bear Lake, shares with the Belgian Congo the source of nearly all the world's radium. The Canadian output has caused a considerable fall in the price of radium in recent years. 